
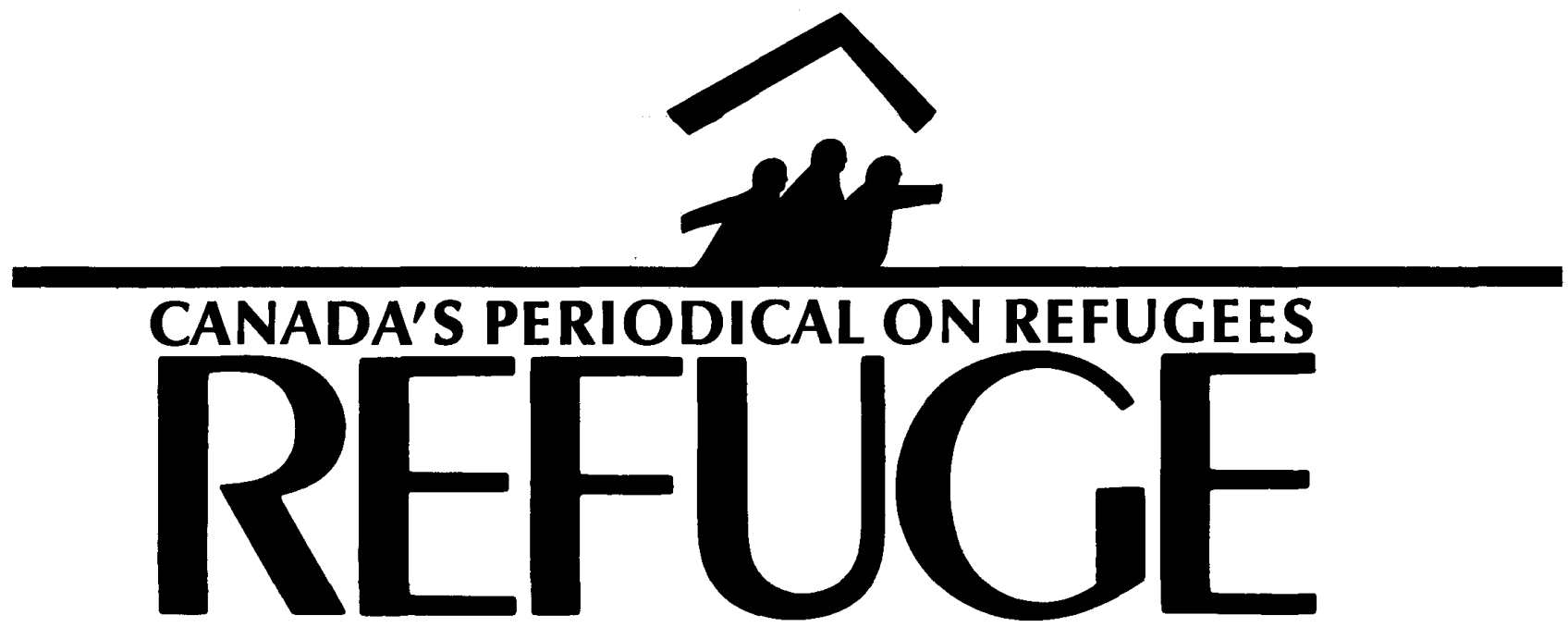

Vol. 2, No. 5

June 1983

\title{
The Refugee Crisis
}

Ten million refugees! Sixteen million refugees! But the real crisis is not simply one of numbers or even of the degree of hardship, both physical and emotional, suffered by all those who are homeless. The real crisis is a moral and political one.

Our globe is completely divided up into states. There are virtually no more nomads. The era of unsettled peoples who moved with lightning speed to conquer new pastures or hunting lands ended in Eurasia in the 17th century, in China and India in the 18th century, in the Americas in the 19th century and in Africa in the 20th century. Corresponding to the disappearance of nomadic life has been the disappearance of frontiers, of the conquest and settlement of "virgin" lands whether in Siberia, the Americas, or the continent of Africa. Settlers from diverse areas had to be consolidated into nations. Frontiers had to be converted into secure and recognized borders.

The 20th century has witnessed the evolution of a world-wide nation-state system with the result that any individual today who is not a citizen is, by definition, stateless, and hence, homeless. In this century, to be stateless, and hence, homeless, is to be cast out of humanity. The only way to have a home and thus to avoid being an "outsider" is to belong to a state: citizenship, therefore, has become not simply a duty, but a necessity and a right. It is a prere- quisite to living in our contemporary world.

If every individual must be a citizen, the corollary is that states must fulfill fundamental obligations to individuals. First, the protection of its individual citizens from domestic strife and foreign enemies must be a priority of a state. Second, each citizen must be treated equally before the law. Third, the state has an obligation to foster conditions which allow citizens to develop and secure their own prosperity, professional achievement and creativity.

Difficulties arise when states fail in their obligations to their citizens. Rather than functioning as protectors, the governors of a state may actually endanger and threaten its own citizens; rather than guaranteeing equality before the law, the rulers may persecute individuals or groups either by legal means or through individuals and groups not subject to rule of law; rather than fostering opportunities for their citizens, dictators or oligarchies may be their chief exploiters.
A moral and political crisis, however, is experienced in those states which take seriously the obligations to their own citizens and also assume some obligation to the suffering individuals of other states. The Canadian government has an obligation to protect our security, guarantee equal treatment under the law, and provide opportunities for the selfrealization of its individual citizens. The government has also written into domestic law and entered into international obligations for the protection of refugees who flee governments which act contrary to their obligations to their own citizens.

What happens when international obligations threaten or appear to threaten the obligations governments have to their own citizens? What happens when the government fails to ensure opportunities for its own citizens at the same time as the numbers of refugees are increasing? Moral obligations to others who are victims of exploitation by their (Continued on $p .3$ )
ALSO FEATURED IN THIS ISSUE. . . . . . . . . . .

DETAINING AND PROSECUTING REFUGEE CLAIMANTS

by Stephen Foster........................... 4

HUMAN RIGHTS IN LATIN AMERICA: SUMMARY OF A REPORT BY CANADIAN CHURCH GROUP ...........6

EQUALIZATION TO INTEGRATION: PRIVATE AND

GOVERNMENT SPONSORSHIP $\ldots \ldots \ldots \ldots \ldots \ldots \ldots \ldots \ldots \ldots$ 
REFUGE

c/o Refugee Documentation Project York University, 4700 Keele Street, Downsview, Ontario M3J $2 R 6$

\section{Editor:}

Howard Adelman

Managing Editor:

Caroline Stephens

Editorial Assistant:

Dan Shea

Editorial Board:

Douglas Cohen, Montreal

Claudio Duran, Toronto

Arie van Eek, Burlington

Donald Ferguson, Toronto

James Hathaway, Moncton

Michael Pitman, Toronto

Linda Weigl, Regina

Typesetting and Layout:

Publications Department,

York University

Refuge is dedicated to encouraging assistance to refugees, by providing a forum for sharing information and opinion on Canadian and international issues pertaining to refugees. It is published five times a year, in October, December February, April and June. It is a non-profit, independent periodical supported by grants from the Canadian Foundation for Refugees, Canada Employ ment and Immigration Commission; by private donations; and by subscription payments of $\$ 10$ a year. It is a forum for discussion, and the views expressed do not necessarily reflect those of its funders, staff or Editorial Board.

All material in Refusc may be reproduced without permission unless copyrighted or otherwise indicated. Credit should be given to the author or source if named.

\section{Logo design:}

Dreadnaught Cooperative Inc., Toronto

Second Class Mail Registration No. 5512 ISSNO229-5113

\section{Books Received}

Canada as a Principal Power, David B. Dewitt and John J. Kirton. John Wiley and Sons Canada Limited. Toronto. 1983. Chapter 7, "Immigration Policy: The Case of Refugees" is particularly relevant.

$$
\text { *** }
$$

The State of the World's Children, 1982-83, James P. Grant, Executive Director of the United Nations Children's Fund. Oxford University Press. New York, 1982.

\section{Letters}

To the Editor,

L'article paru dans Refuge Vol 2, no.3 sur les réfugiés du Sud-Est asiatique en France, contient certaines inéxactitudes et permettez-moi de vous apporter à ce suject quelques précisions.

La Commission de recours qui juge du bien fondé ou non du refus d'attribution par l'OFPRA du statut de réfugié au sens de la Convention de Genève ne comprend pas en son sein un représentant de l'OFPRA mais un représentant du Ministère de la Solidarité $\mathrm{Na}$ tionale (anciennement Ministère du Travail). Le représentant de l'OFPRA n'est là que pour tenter de justifier devant la Commission le refus apposé à un dossier. En aucun cas, il est juge en la circonstance.

Seul l'OFPRA est habilité en France à attribuer à un étranger le statut de réfugié politique. C'est donc lui qui a attribué le statut de réfugié politique aux personnes déplacées du Sud-Est asiatique. Mais il est vrai que ces mêmes personnes l'ont obtenu, dans la plupart des cas, dans le cadre d'une politique d'ensemble et non pas après examen cas par cas des dossiers comme il est normalement de règle.

En aucun cas, la délégation du HCR en France a participé à une quelconque politique de sélection des réfugiés dans les pays de transit. Tout au plus, peutil formuler quelques souhaits. Il y a eut des opérations d'accueil de réfugiés en France qui n'ont pas reçu l'adhésion du $\mathrm{HCH}$, bien au contraire. Par exemple, je pense à l'opération dite des "enfants de Noël" qui concerna un peu plus d'une centaine de mineurs isolés cambodgiens en décembre 1980.

Il y aurait beaucoup à dire sur la politique française de sélection des réfugiés du Sud-Est asiatique. Elle a varié dans le temps et les critères appliqués ont souvent changé. A ceux que vous citez, je vourdrais au moins en ajouter un autre: la qualification professionnelle. Au début, il s'agissait de privilégier les hautes qualifications mais ensuite on préféra se tourner vers les "manuels" parce qu'ils étaient ceux qui ressentaient le moins durement un déclassement professionnel.

La carte des centres provisoires d'hébergement (C.P.H.) en France est aussi très changeante. Des centres ouvrent quand d'autres ferment provisoirement ou définitivement et cela assez périodiquement. Il n'est pas question de rentrer ici dans le détail mais globalement on peut dire que les C.P.H. se situent en grande majorité dans la France ditè "industrielle" par rapport à celle dite "rurale", c'est-à-dire dans la moitié est du pays.

Les allocations attribuée aux réfugiés dans les C.P.H. sont heureusement supérieures à celles que vous mentionnez. En 1979-1980 elles étaient de $10 \mathrm{~F}$. par jour par adulte et de $2 \mathrm{~F}$. par jour par enfant de moins de 15 ans en plus de la fourniture gratuite de la nourriture, soit pour un adulte un minimum de $70 \mathrm{~F}$ par semaine au cours des premiers mois, d'accueil. Cette somme était loin d'être un luxe quand on songe qu'elle n'avait pas progréssé depuis 1975 malgré un forte inflation.

En ce qui concerne les solutions individuelles, le Secours Catholique, contrairement au SSAE n'a jamais été habilité à subvenir aux besoins des réfugiés autrement que par des aides ou des dons dont il assurait l'entière responsabilité sans qu'elle relevât en rien de l'Etat. Tout au plus, peut-il agir comme intermédiaire pour tansmettre des dossiers aux autorités reconnues et compétentes.

A aucun moment, je pense, on peut parler de coercition quant à l'implantation des C.P.H. dans les départments français. La persuasion que vous évoquez est le terme exacte aussi bien avant qu'après l'accession des Socialistes au pouvoir en mai 1981.

Vous avez raison de souligner, je crois, qu'on a essayé en France d'insérer les personnes sans dresser de clivages ethniques comme cela a été le cas lors du rapatriement des Français musulmans d'Afrique du Nord vers 1960. Malheureusement, ce clivage ethnique vient quelquefois des ethnies minoritaires elles-mêmes qui peuvent avoir tendance à se replier sur elles du fait même qu'elles sont minoritaires.

Michel Mignot, Centre De

Documentation et de Recherches sur L'Asie du Sud-Est et Le Monde Insulindien (CeDRASEMI) Valbonne, France

Michel Mignot's observations concerning formalities and other arrangements for resettlement of refugees in France are important. Some of my own observations on these issues were omitted from a longer draft of my article.

C.M. Lanphier 


\section{The Refugee Crisis \\ (cont'd from p. 1)}

own governments tend to be reduced. Considerations of equality before the law are restricted to citizens (thus excluding refugees who might have benefited from them); but these same restrictions are removed when such considerations can be applied to the detriment of refugees. In some cases, even our obligation to individuals whose physical security is actually threatened may be affected. This is the source of the moral and political crisis.

Canada's economic crisis is part of a world crisis which has fostered situations in which the number of refugees has increased. At the same time, pressure mounts to keep them out; the government is urged to attend to its own citizens who lack adequate housing or any employment. We do not believe we can fulfill our obligations to our own citizens as well as our obligations to refugees. What do we do?

There are people today whose economic welfare has been totally undermined by their own government's policies. They live on the edge of despair, revolt or risk death to flee to a new situation which might offer a glimmer of hope. To counteract the flow of these increasing numbers of economic refugees, we have begun to restrict our humanitarian programs even toward those emanating from territories governed by economic systems contrary to our own. In the past, our humanitarian refugee program has not been geared to respond to the suffering of citizens exploited by their own governments. If the regime was simply a negligent one or even a criminal one, as in Haiti, we did not consider those who fled the economic exploitation to be refugees. However, when policies denying economic opportunities were ideologically motivated we used our humanitarian programs to help those who fled. We extended an outstretched hand to East Europeans but not Haitian selfexiles. The degree of intake was not proportionate to the degree of exploitation and suffering but was related to the ideology of a system regarded as contrary to our own. But even the humanitarian programs applied to the latter group become more restrictive.

Judicial norms are distorted to restrict the entry of refugees fleeing regimes which offend all norms of justice. The principle of equality before the law is applied where it is inapplicable and, along with the principle of mitigating circumstances, both are ignored where they are relevant. For those who live in countries where there is no equality of treatment before the law, where justice is swift, arbitrary and not itself subject to judicial norms, there is a legitimate fear of persecution. But to enter Canada these individuals may breach our laws - lie on their declarations of entry or alter a passport. To them we may apply the principle of equality before the law even if they are genuine refugees; because they breach our laws, immigration officers may determine that such individuals cannot be given refuge. To others, we deny equality before the law because we do not insist on the right of refugee claimants to be represented by counsel. The principle of equality before the law, which is a procedural norm, is not used to ensure procedural equality. It is distorted and applied to the offence, in spite of the fact that another judicial norm requiring a consideration of mitigating circumstances to ensure justice would clearly differentiate between a situation in which a refugee who flees a government he does not trust and alters a passport to obtain a safe haven as very different from a case in which one of our own citizens alters a passport for criminal purposes.

In the area of pure protection, where the physical security of the refugee is clearly in danger, our refugee policy seems to serve impartially. The onus of proof is on those who must establish a fear of persecution, though they may be given the benefit of the doubt.

Granting asylum for those who flee in fear of their lives is a litmus test of whether a government has a refugee policy. The degree of liberalization of that policy, however, is measured by two other yardsticks. First, is the principle of equality before the law applied to the judicial norms for processing a claim and not to particular offences? If it is, the policy is liberal. Second, are the humanitarian policies applied in relationship to the degree of exploitation and suffering of those who flee independent of whether that exploitation is rooted in ideological or criminal motives? If it is, the refugee policy is ultra-liberal.

Our doors are not shut to refugees. But they are closing. The forces favouring restrictive policies, focussing on the welfare of our own citizens at the expense of refugees, seem to be in the ascendant compared to the forces for liberalization.

\section{Canadian News}

\section{Indochinese Arrivals - We're Slipping}

Canada admitted 112 Indochinese refugees for resettlement in February and 189 in January of this year. During the same two-month period, Australia admitted 1,468 , the U.S.A. 3,224, France 828 and Germany 223. Little New Zealand took in 81 and even Finland admitted 119. What happened to Canada's leadership role in providing third country resettlement for these refugees?

\section{Anti-Piracy Program}

Canada and 11 other countries are attempting to find ways of extending a program to combat pirate attacks against Indochinese "boat people" on the South China Sea. The program has led to a decrease in these armed attacks since it began last August. Donations in 1982 totalling U.S. $\$ 3.6$ million from 12 countries, including $\$ 150,000$ from Canada, helped the government of Thailand to carry out operations against such attacks. There is a need for further funding to ensure that anti-piracy operations will continue.

Over 1,400 Vietnamese left their country in March under the Orderly Departure Program organized by UNHCR. This compares to the departure of 1,661 "boat people" in the same month.

\section{Toronto Office Skills Training Project}

The Toronto Office Skills Training Project, funded by L.E.A.P. (Local Employment Assistance Programme) has been established to prepare women from Southeast Asia for clerical work in offices. The project is designed to offer an integrated program of ESL instruction with training in job skills, life skills and on-the-job training. The project went into operation on May 9 with its first group of trainees. For more information contact Janis Galway at 69 Sherbourne Street, Suite 421, Toronto, Ontario M5A 3X7. Phone (416) 3689355. 